\title{
反射強度を用いた走行可能領域の認識に基づく交差点検出
}

\author{
草刈 亮輔 ${ }^{* 1}$, 恩田 知弥 $* 1$, 山田 就策 $* 2$, 黒田 洋司 $* 3$
}

\section{Intersection detection based on recognition of drivable region using reflection light intensity}

\author{
Ryosuke KUSAKARI $^{* 1}$, Kazuya ONDA*1, Shusaku YAMADA*2 and Yoji KURODA*3 \\ ${ }^{*} 1,{ }^{*}$ Graduate School of Science of Technology, Meiji University \\ 1-1-1 Higashimita, Tama-ku, Kawasaki-shi, Kanagawa 214-8571, Japan \\ ${ }^{*}$ School of Science of Technology, Meiji University \\ 1-1-1 Higashimita, Tama-ku, Kawasaki-shi, Kanagawa 214-8571, Japan
}

Received: 12 February 2019; Revised: 19 April 2019; Accepted: 5 June 2019

\begin{abstract}
In the conventional intersection recognition method, shape information is used. In order to recognize an intersection composed of roads divided by grass and asphalt, it is necessary to distinguish them. There is almost no difference in shape between grass and asphalt. For this reason, it is difficult to distinguish them by the method using shape information. Therefore, we use reflection intensity by LiDAR to distinguish grass and asphalt. In this paper, we compare the reflection intensity of the ground surface at points where distances from LiDAR are equal. The appropriate threshold for distinguishing materials of the ground is dynamically calculated for each distance using Discriminant Analysis Method. We accumulate the drivable region using the dynamically calculated threshold value in chronological order taking the relative movement amount into account. We add probabilistic processing to the drivable region accumulated in chronological order to extract more stable drivable region. Finally, an intersection is detected by combining the drivable region extracted using the reflection intensity and the drivable region extracted using the shape information. Intersection detection method uses Toe-Finding Algorithm. In order to show the usefulness of our method, we compare our method with two method, Partition Line Method and the proposed method unaccumulated the drivable region.
\end{abstract}

Keywords : Autonomous mobile robot, Intersection detection, Reflection light intensity, Static obstacle, 3D-LiDAR

\section{1. 緒言}

近年，自律移動ロボットに注目が集まる中で，警備や配達等の人間の業務を代替することを目的としたロボット の開発が盛んに行われている。これらのロボットが常に変化し続ける実世界で活躍するためには，その場の環境 に適応する必要がある. 自律移動ロボットの研究では, 事前情報として走行環境の形状地図を基に自己位置推定 を行う手法（Saarinen et al., 2013）（Armesto et al., 2010）が多く提案されている. しかし，これらの手法は，環境 が変化する度に事前情報の地図を作り直す必要があるため, 広大で環境の変化の大きい屋外で用いるには不向き である．そこで，環境の変化に適応するために，電子地図を利用した手法の開発（Hosoda et al., 2018）や道なり に走行をする手法の開発が行われている（渡辺他, 2012）。これらの研究では, 交差点の検出を利用した自己位置 推定と誘導を行っている.

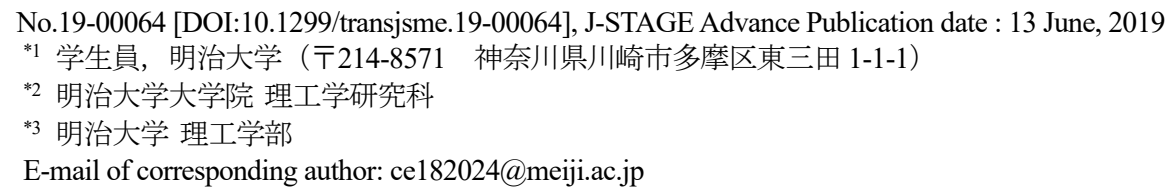


従来の交差点を認識する手法（Chen et al., 2011）（Zhang et al., 2015）は, UGV を対象としたものが多く, 周囲 の形状情報を利用して走行可能領域を抽出することで交差点認識を行っている.しかし，これらの手法では，幾 何学的特徵が乏しい環境の場合, 進入するのに適さない芝や土を判別することは困難である. そのため, 同環境 での交差点検出も困難となる，そこで, 材質や表面の状態により值が異なる反射強度に注目し, アスファルトと 芝や土を判別した研究（Macedo et al., 2001）（伊達他, 2013）や，ロードマーカの検出を行う研究が提案されてい る (Hata and Wolf, 2016) 。一般的に光の強さは光源からの距離に応じて減衰することが知られているため, これ らの手法では材質等の区別をするために得られた反射強度に対して距離の補正を行っている. しかし, 距離に対 する補正式は, 実験的に得ていることが多く曖昧さが残る点や, 材質ごとに減衰の仕方が異なる点から比較が適 切であるとは言い難い.

そこで本研究では, LiDAR からの距離が等しい地点同士で地表面の反射強度を比較する.これにより, 車輪移 動ロボットが走行するのに適さない芝や土と, 走行に適したアスファルトの区別を行う. 以後, アスファルトと推 定した点を走行可能点群と称し, 芝と推定した点を走行不可点群と称する. また, 材質の区別をするための適切 な閾值は, 各環境において異なる.そこで, 各等距離の点群の反射強度に対して, 距離ごとに判別分析法（大津 の 2 值化）（Otsu, 1979）を適用し動的に閾值を算出する. 次に算出した閾値をもとに材質の区別を行った点群に 対し, 相対移動量を考慮して時系列で蓄積する. 時系列で蓄積した点群に対して確率的処理を加え, 仮想ビーム モデル（Thrun et al., 2005）を利用することで走行可能領域を抽出する. また形状情報を用いる上で, 動的障害物 が走行可能領域抽出の妨げとなることがある. そこで本稿では, 静的物体を抽出した形状情報を用いて走行可能 領域を抽出する. 最後に, 反射強度を用いて抽出した走行可能領域と形状情報を用いて抽出した走行可能領域を 組み合わせた領域に対して交差点検出を行う.

本研究の有用性を示すために, 研究学園駅前公園において提案手法と, 走行可能領域の蓄積を行わない手法, 反 射強度の閾值を実験式から求めた手法の比較を行う。

\section{2. 提 案 手 法}

本章では, 幾何学的特徵がそしい環境において, 交差点を検出する手法について述べる. まず, 形状情報を利用 した走行可能領域の抽出法と, 形状情報のみでは進入可否の判断が困難な領域に対して, 反射強度を利用した走 行可能領域の抽出法について述べる. その後, 形状情報と反射強度により抽出した領域を基に交差点を検出する 方法について述べる.

また本手法では, 仮想ビームモデルを利用し, 走行可能領域を抽出する. 仮想ビームモデルは S. Thrun（Thrun et al., 2005）によって提唱されたビームモデルを使用する. ビームモデルとは, ある初期点から均等な角度で障害 物までの距離を測るモデルのことである。ここでLiDAR から得られる情報を式（1）に示し, ビームモデルを, 式 (2) に示す.

$$
\begin{aligned}
& P:=\left\{p_{k} \mid p_{k} \in \mathbb{R}^{3}, k=0,1, \ldots, N\right\} \\
& \left\{\begin{array}{l}
Z_{k}:=\left\{\frac{(k-1) \pi}{n^{\prime}}<\tan ^{-1}\left(\frac{y-y_{\text {ini }}}{x-x_{\text {ini }}}\right) \leq \frac{k \pi}{n^{\prime}}|| x\left|\leq r_{\text {max }},\right| y \mid \leq r_{\text {max }}, k=1,2,3, \ldots, n^{\prime}\right\} \\
d_{k}:=\left\{\min \sqrt{x_{j}^{2}+y_{j}^{2}} \mid p_{k} \in Z_{k}, k=1,2 \ldots, n^{\prime}\right\}
\end{array}\right.
\end{aligned}
$$

ここで, $Z_{k}$ は $\mathrm{k}$ 番目のビームゾーン領域, $n^{\prime}$ は分解能, $d_{k}$ は, ビームゾーン $\mathrm{k}$ 内の点 $p_{k}$ 間の最短距離を表す, $r_{\text {max }}$ はビームの最大の長さ, $x_{i n i}, y_{i n i}$ はビームモデルの発射点を意味する

本手法では, ビームモデルの初期点を, 距離情報を取得している LiDAR の場所とする. また, 本稿において, ビームモデルから得た走行可能領域を緑の線で表す.

\section{$2 \cdot 1$ 形状情報を用いた走行可能領域抽出}

\subsection{1 障害物抽出}

本研究では, 高さ変化が大きい障害物の抽出を行う Min-Max 法（Thrun et al., 2006）を用いることで, 形状情 報による走行可能領域を抽出する.Min-Max 法は水平面を格子状に区切り，式（3）に示すように各格子内に含ま

Iより正確には光センサが感知した受光強度というべきだが, 本論文中ではこれを”反射された光の受光強度” の意味で反射強度と表記する. 


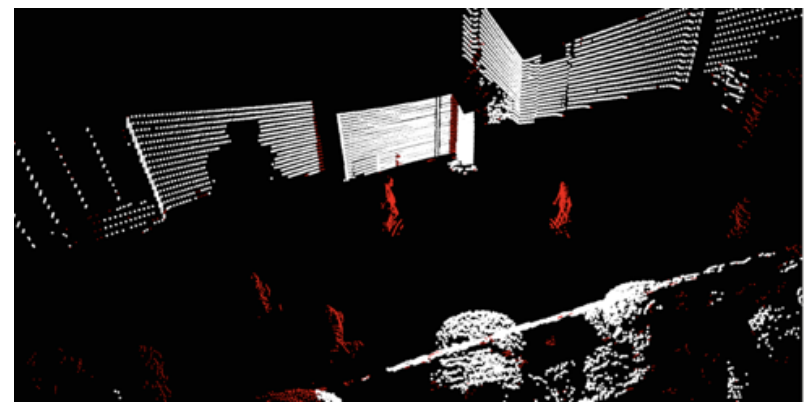

(a)

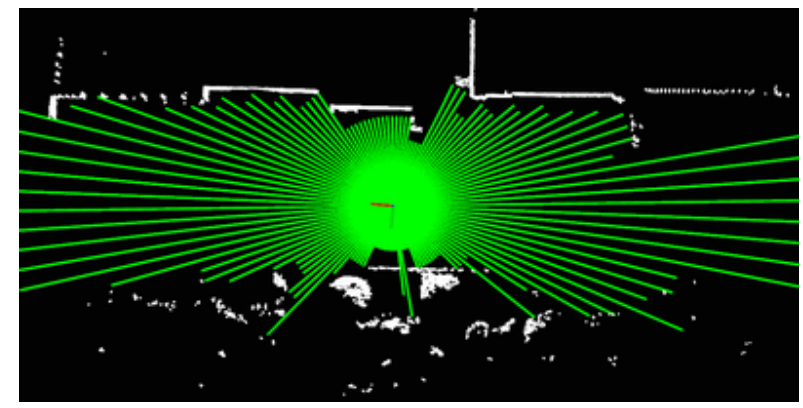

(b)

Fig. 1 Image(a) shows that static obstacles extracted from obstacles obtained by Min-Max Method. White points show static obstacles, and red points show dynamic obstacles. Here, The obstacle point whose propability that is static is higher than 0.7 extracts as static obstacles. Image(b) shows drivable region using static obstacles.Green lines show drivable region using beam model.

れる点群 $P^{\prime}$ を最大值，最小值 の差が闇值 $V_{d i f}$ を超えた場合，その格子に障害物があると判別する手法である.こ れを用いて高さのある障害物を認識する.

$$
\max P_{i}^{\prime}-\min P_{i}^{\prime}>V_{\text {dif }}
$$

\subsection{2 確率的処理による動的物体除去}

実環境において，歩行者などの動的物体が走行可能領域検出の妨げとなる場合がある．そこで本研究では，高 さのある障害物として抽出した点群をロボットの移動量を考慮し蓄積することで，動的物体の判断及び除去を行 う．点群を時系列で比較するために，LiDAR 座標系で取得した点群を，オドメトリ座標系に座標変換する．座標 変換の式を式（4）に示す.

$$
{ }^{\text {odom }} p_{k}=\mathbb{R} \times{ }^{\text {lidar }} p_{k}+t
$$

ここで, ${ }^{l i d a r} p_{k}$ は座標変換前の点群を, ${ }^{\text {odom }} p_{k}$ は座標変換後の点群を, $\mathbb{R} \in S O(3)$ はオドメトリの回転方向を, $t \in \mathbb{R}^{3}$ はオドメトリの並進方向をそれぞれ示す．座標変換後，数 step に及び点群を蓄積していく.

取得した点が静的物体で構成されているかの判断は，占有格子の基本的な概念に基づいた処理で行う. 本研究 では，2 次元格子を用いる. 一般に， 2 次元格子は 2 次元配列として扱われることが多く，格子地図 M に対して 式（5）として与える.

$$
M:=\left\{m_{(0,0)}, m_{(1,0)}, \ldots, m_{(x, y)}, \ldots, m_{\left(l_{x}, l_{y}\right)}\right\}
$$

$m_{(x, y)}$ は位置（x,y）における格子を示す. $l_{x}, l_{y}$ はそれぞれ格子地図の大きさを示す. $m_{(0,0)}$ は LiDAR の位置とする. 各時刻の点群から各格子の状態 $m_{(x, y)}$ を占有, 非占有, 未知の状態で表現する. 静的物体である確率は, 格子 の占有と非占有である回数から占有だけの回数の割合で求める.この確率が閾值 $\delta_{\text {obstacle }}$ を満たさない格子 $m_{(x, y)}$ に属する点を動的物体とみなし，除去する．Min-Max 法により抽出された障害物の点群に対して，時系列的に点 群が占有した確率が $\delta_{\text {obstacle }}$ 以上である静的物体とそれ以外の動的物体を判別した図を図 1 (a) に示す. 抽出した 静的物体に対して, 式（2）より各角度のビームゾーンの最短距離を算出する. 図 1（a）の静的物体に対して, 仮 想ビームモデルを使用して走行可能領域を抽出した図を図 1（b）に示す.

\section{$2 \cdot 2$ 反射強度を用いた走行可能領域抽出}

\subsection{1 極座標格子}

本節では，ある距離に投射された点同士での反射強度の比較するために，LiDAR 座標系で得られる高さのある 障害物以外の点群を, LiDAR を中心とした極座標系に変換し，格子で区切る手法について述べる．ここで用いる 点群とは，式（3）より闇值 $V_{\text {dif }}$ を超えない格子に含む点群のことを示す．本手法では，LiDAR から得られる式 


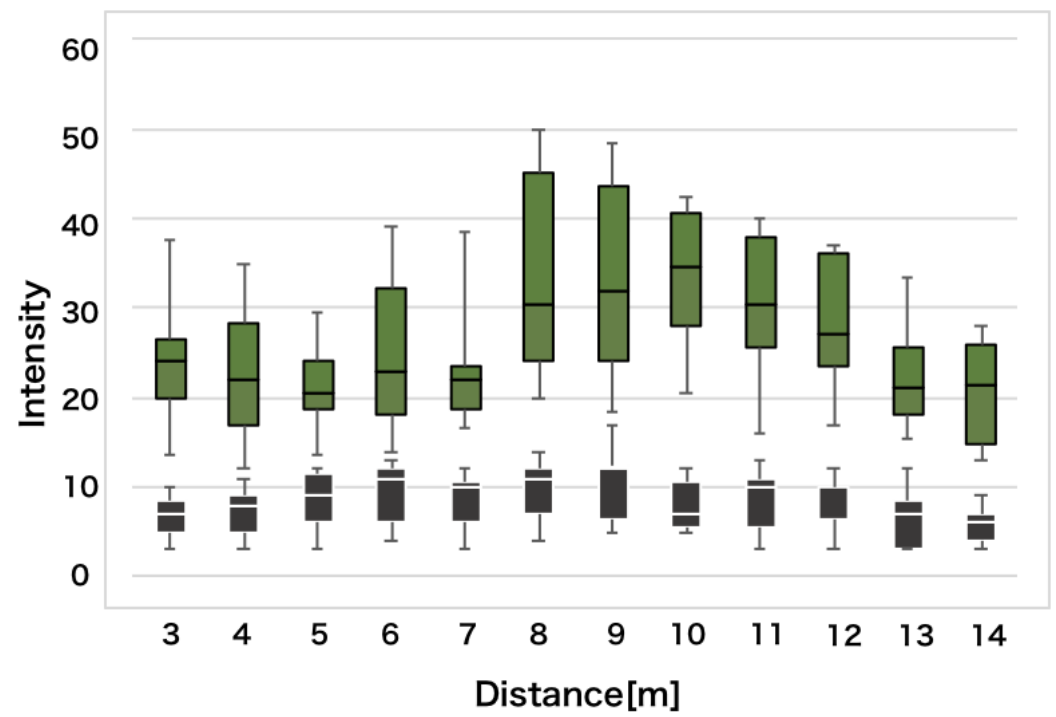

Fig. 2 Reflection intensity data at the ground of Kenkyugakuenmae park that is an experimental environment. This graph represents their data as their box plot. The green box shows reflection intensity of grass. The black box shows reflection intensity of asphalt.

（1）を，式（6）を用いて変換する.

$$
\left\{\begin{array}{l}
r_{k}=\left\{\sqrt{\left(x_{k}^{2}+y_{k}^{2}\right)} \mid 0<r_{k} \leqq r_{\max }\right\} \\
\theta_{k}=\left\{\arctan \left(y_{k} / x_{k}\right) \mid 0<\theta_{k} \leqq 2 \pi\right\}
\end{array}\right.
$$

ここで，ある距離に投射された点同士での反射強度の比較を行うため, 点群の各点を, $\Delta r$ と $\Delta \theta$ で区切られた極 座標格子に入れる. 各点を極座標格子に入れることにより, $\Delta r$ 間にある点同士の比較を可能とする. また, $\Delta r$ と $\Delta \theta$ で区切られた領域が進入可否の判定を格子単位で行う. ある格子 $\left.m_{(} r_{i}, \theta_{j}\right)$ に投射された点群が保持する反射強 度を式 (7) より平均した值 $\Gamma_{\left(r_{i}, \theta_{j}\right)}$ を用いる。

$$
\Gamma_{\left(r_{i}, \theta_{j}\right)}=\left\{\begin{array}{ll}
1 & m_{\left(r_{i}, \theta_{j}\right)} \\
\frac{1}{n} \sum_{k}^{n} \gamma_{\left(r_{k}, \theta_{k}\right)} & r_{i} \leqq r_{k}<r_{i}+\Delta r \\
& \theta_{j} \leqq \theta_{k}<\theta_{j}+\Delta \theta
\end{array}\right\}
$$

$n$ は格子内に属する点の個数, $\gamma_{\left(r_{k}, \theta_{k}\right)}$ は, 点の反射強度を示す. 平均した值 $\Gamma_{\left(r_{i}, \theta_{j}\right)}$ を用いて, 走行可能領域の抽出 を行う.

\subsection{2 格子進入可否判定法}

本節では，等距離にある格子同士の比較から，車輪移動ロボットが走行するのに適さない芝や土と，走行に適す るアスファルトの区別する手法について述べる. 本手法の有用性を示すための実験を行った研究学園前公園内の 一部の区間における反射強度の值を図 2 に示す。この実験に使用した LiDAR は Velodyne 社の HDL-32e を使用し た。 また LiDAR は, ロボット接地面から $1.3 \mathrm{~m}$ の高さに設置した．図 2 からアスファルトに対して, 芝は反射強

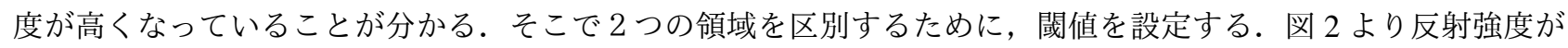
閾值より低い領域を走行可能点群，閾值より高い領域を走行不可点群と判定する．また，領域を分割するための 適切な閾值は, 各環境において異なる.そこで本手法では, 極座標格子に対して, 等距離ごとに判別分析法（大 津の 2 值化）に基づいた閾值を設定する.

判別分析法とは，ある值 $\delta^{\prime}$ で 2 つのクラスに分割し，2 つのクラス間の分離度が最も良くなる時の $\delta^{\prime}$ を閾值 $\delta$ として決める手法である. 以下に, 等距離 $r^{\prime}$ にある格子の中の反射強度を基に, 閾値 $\delta_{r^{\prime}}$ を動的に算出過程を示 す. 2 つのクラスに分割する值を $l \in\left[\Gamma_{r_{\text {min }}^{\prime}}, \Gamma_{r_{\text {max }}^{\prime}}\right]$ と置く. $\Gamma_{r_{\text {min }}^{\prime}}, \Gamma_{r_{\text {max }}^{\prime}}$ は, それぞれ等距離 $r^{\prime}$ にある格子の中で反 射強度の最小值と最大值を示す。 
(1) 2 つのクラスそれぞれの平均值, 分散值, 要素数值を求める. ここでは, $\Gamma_{\left(r^{\prime}, \theta_{j}\right)}$ が $l$ 以下のクラスをクラ ス 1 とし, $l$ 以上をクラス 2 とする.

$$
\begin{aligned}
& \left\{\begin{array}{l}
m_{1}^{\prime}:=\left\{\sum_{j=0}^{n^{\prime}} \Gamma_{\left(r^{\prime}, \theta_{j}\right)} \mid \Gamma_{\left(r^{\prime}, \theta_{j}\right)} \leqq l\right\} \\
m_{2}^{\prime}:=\left\{\sum_{j=0}^{n^{\prime}} \Gamma_{\left(r^{\prime}, \theta_{j}\right)} \mid \Gamma_{\left(r^{\prime}, \theta_{j}\right)}>l\right\}
\end{array}\right. \\
& \left\{\begin{array}{l}
\omega_{1}:=\left\{\sum_{j=0}^{n^{\prime}} j \mid \Gamma_{\left(r^{\prime}, \theta_{j}\right)} \leqq l\right\} \\
\omega_{2}:=\left\{\sum_{j=0}^{n^{\prime}} j \mid \Gamma_{\left(r^{\prime}, \theta_{j}\right)}>l\right\}
\end{array}\right. \\
& \left\{\begin{array}{l}
\mu_{1}:=\left\{\frac{1}{\omega_{1}} \sum_{j=0}^{n^{\prime}} \Gamma_{\left(r^{\prime}, \theta_{j}\right)}-m_{1}^{\prime 2} \mid \Gamma_{\left(r^{\prime}, \theta_{j}\right)} \leqq l\right\} \\
\mu_{2}:=\left\{\frac{1}{\omega_{2}} \sum_{j=0}^{n^{\prime}} \Gamma_{\left(r^{\prime}, \theta_{j}\right)}-m_{2}^{\prime 2} \mid \Gamma_{\left(r^{\prime}, \theta_{j}\right)}>l\right\}
\end{array}\right.
\end{aligned}
$$

（2）各クラス内分散を求める.

$$
\mu_{w}{ }^{2}(l)=\frac{\omega_{1} \mu_{1}^{2}+\omega_{2} \mu_{2}^{2}}{\omega_{1}+\omega_{2}}
$$

（3）各クラス間分散を求める.

$$
\mu_{b}^{2}(l)=\frac{\omega_{1} \omega_{2}\left(m_{1}^{\prime}-m_{2}^{\prime}\right)^{2}}{\left(\omega_{1}+\omega_{2}\right)^{2}}
$$

(4) クラス間分散とクラス内分散の比の分離度を求める.

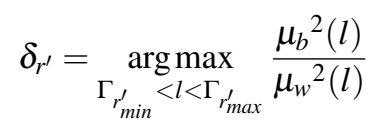

分離度が最も高い時の $\delta_{r^{\prime}}$ を $r^{\prime}$ での格子の閾值とする.

ここで $\omega_{1}, \omega_{2}$ は各クラスに属する格子の数を示す. また, $m_{1}^{\prime}, m_{2}^{\prime}$ は, 各クラスの反射強度の平均值, $\mu_{1}, \mu_{2}$ は, 各クラスの反射強度の分散值, 等距離 $r^{\prime}$ にある格子での反射強度が閾值 $\delta_{r}^{\prime}$ 以下である格子内の点を走行可能 点群と判定する. 閾值 $\delta_{r}^{\prime}$ 以上である格子内の点を走行不可点群と判定する. 判定結果をそれぞれの点群に值を与 え，式（14）のように lidar $p_{\text {road }}$ として保持する.

$$
{ }^{\text {lidar }} p_{\text {road }}= \begin{cases}1 & \left(\Gamma_{\left(r_{i}, \theta_{j}\right)} \leqq \delta_{r^{\prime}}\right) \\ 0 & (\text { otherwise })\end{cases}
$$

\subsection{3 確率的処理による走行可能領域抽出}

2.2.2 において，LiDARの 1 スキャンごとの反射強度を基にした進入可否判定を行った。しかし，1 スキャンに よる判定は安定性に欠け合理的ではない，そこで本研究では，2.2.2で得られた ${ }^{l i d a r} p_{\text {road }}$ を時系列に蓄積し，確率 的に進入可否の判定を行う. 式 (4) より算出した ${ }^{l i d a r} p_{\text {road }}$ を, オドメトリ原点を中心とした位置に座標変換を行 う. 座標変換後, 数 step に及び点群を保持していく. 図 3（a）に lidar $p_{\text {road }}$ の点群を示し, 座標変換後の ${ }^{\text {odom }} p_{\text {road }}$ を蓄積した点群を図 3 （b）に示す．水色の点は走行不可点群を示し，黄色の点は走行可能点群を示す.

図 3 （b）を，現時刻での LiDAR からみた極座標格子に入れる. 各極座標格子内の走行可能領域である確率 $P_{m}\left(r_{i}, \theta_{j}\right)$ を, 式（15）より算出する.

$$
P_{m\left(r_{i}, \theta_{j}\right)}=\left\{\begin{array}{ll} 
& m_{\left(r_{i}, \theta_{j}\right)} \\
\frac{1}{n} \sum_{k}^{n}{ }^{\text {odom }} p_{\text {road }} \mid & r_{i} \leqq r_{k}<r_{i}+\Delta r \\
& \theta_{j} \leqq \theta_{k}<\theta_{j}+\Delta \theta
\end{array}\right\}
$$




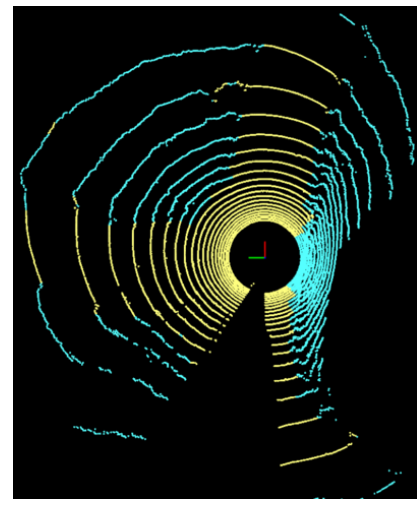

(a)

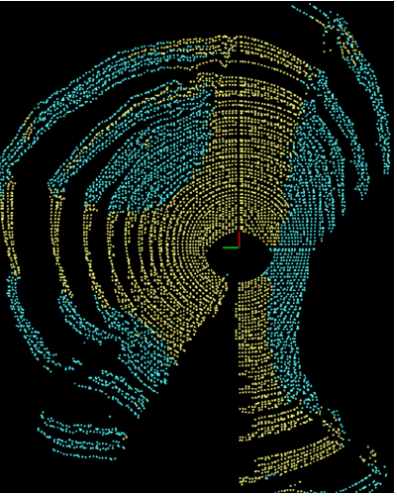

(b)

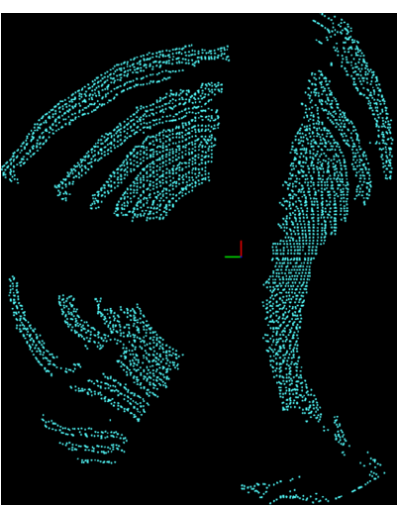

(c)

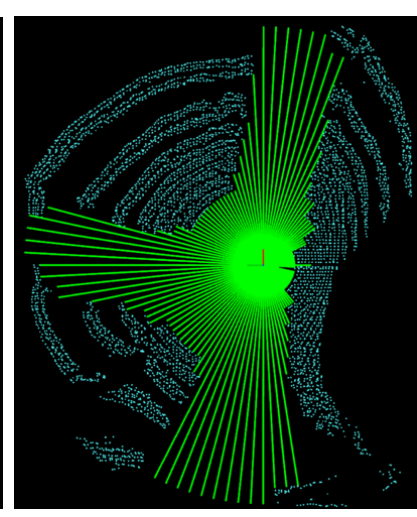

(d)

Fig. 3 Image(a) shows the result of discriminating the material of the ground. Yellow points represent point cloud discriminated as drivable region. Light blue points represent point cloud discriminated as undrivable region. Image(b) shows discriminated point clouds are accumulated. when it accumulate point cloud, we consider the moving amount of the robot. Image(c) shows lower points than the probability threshold $\delta_{\text {drivable }} . \delta_{\text {drivable }}$ sets 0.5 . Image(d) shows obtained drivable region using lower points than $\delta_{\text {drivable }}$.

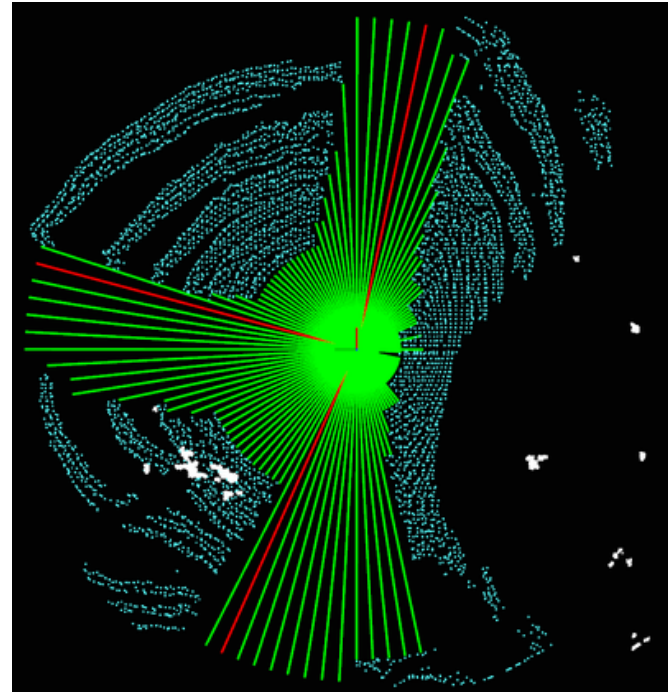

(a)

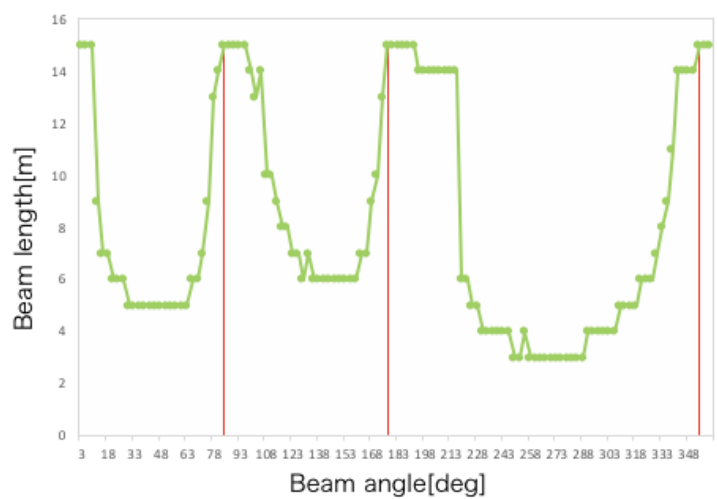

(b)

Fig. 4 Image(a) shows intersection detection. The used region to detect the intersection are things that the extracted drivable region by reflection intensity and the extracted drivable region by static obstacles are integtated. Red lines show peak estimated by Toe-Finding Algorithm based on the region. Image(b) shows distance function.

走行可能点群である確率 $P_{m\left(r_{i}, \theta_{j}\right)}$ が閾值 $\delta_{\text {drivable }}$ を満たさない格子 $m_{\left(r_{i}, \theta_{j}\right)}$ を進入に適さない領域とみなす. 図 3 （b）に対して，進入に適さない領域として抽出した点群を図 3 （c）に示す。図 3 (c) を基に，仮想ビームモデル を使用して走行可能領域を抽出した図を図 3 (d) に示す.

\section{$2 \cdot 3$ 交差点検出}

本手法では，Hu ら（Hu et al., 2007）が提案した Toe-Finding Algorithm に基づいたピーク検出を行う. 図 1（b） に示した形状情報による走行可能領域と，図 3 (d) に示した反射強度による走行可能領域を統合してピーク検出 を行う. 図 4（a）に交差点を検出している様子を示す. 赤色の線はピーク検出法によって検出した連続性の高い 路面を表している. この赤い線の本数から交差点検出を行う. また図 4（b）は，対応する距離関数を示している. 


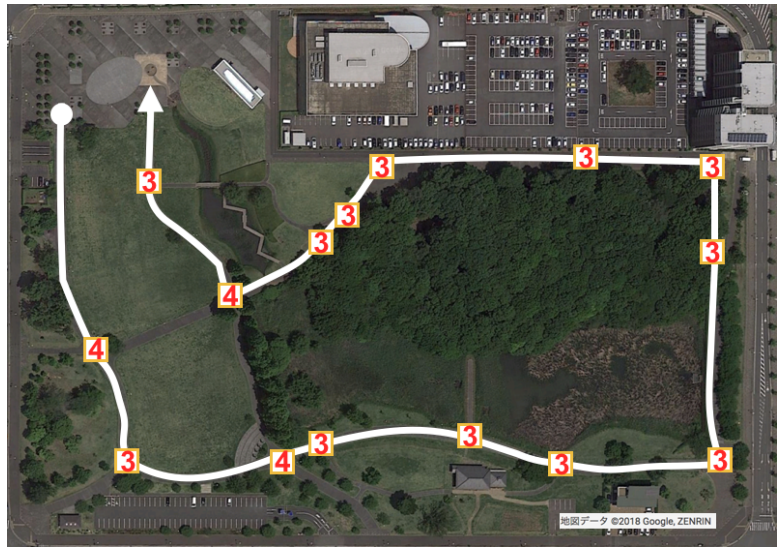

(a)

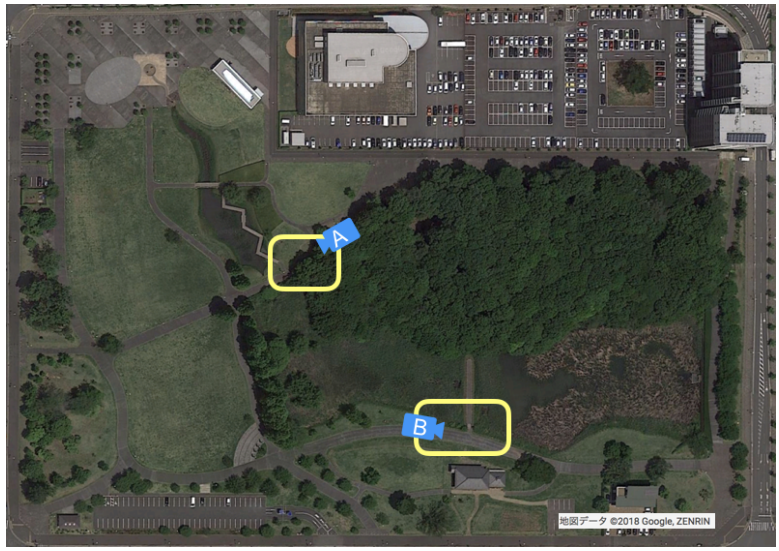

(b)

Fig. 5 The experimental environment. White line shows experiment route. Yellow squares show intersection. Red number in yellow square shows the number of peak against intersection.

Table 1 Evaluation results

\begin{tabular}{|c|c|c|c|}
\hline & Proposed Method & Unaccumulated Method & Partition Line Method \\
\hline Precision(\%) & 89.7 & 82.8 & 62.9 \\
\hline Recall $(\%)$ & 86.7 & 80.0 & 73.3 \\
\hline Accuracy(\%) & 88.7 & 82.3 & 66.1 \\
\hline
\end{tabular}

\section{3. 実 験及び結 果}

\section{$3 \cdot 1$ 実験概要}

提案手法の有用性を示すために, 図 5 に示す幾何学的特徵がそしい環境で交差点検出の精度評価を行う。実験日 は 2018 年 9 月 15 日と 2018 年 10 月 13 日で行った。本研究では，ホイールエンコーダによる並進速度と IMUによ る回頭速度からオドメトリを算出する. 使用する LiDAR は, Velodyne HDL-32E を用いる. 使用したパラメータは, $r_{\text {max }}=15.0 m, \Delta x=\Delta y=0.2 m, \Delta r=1.0 m, n^{\prime}=120, \Delta \theta=2 \pi / n^{\prime} \mathrm{rad}, V_{\text {dif }}=0.15 \mathrm{~m}, \delta_{\text {obstacle }}=0.5, \delta_{\text {drivable }}=0.5$ とした。時系列処理する上で $4 \mathrm{~Hz}$ で 15 step 分の点群を蓄積した. Toe-Finding Algorithm に基づいたピーク検出を 行うために, $\varepsilon_{1}=0.60, \varepsilon_{2}=10, \varepsilon_{3}=0.8$ とした. 反射強度を用いた走行可能領域抽出法を異なる手法と比較す ることで有用性を示す. また形状情報を用いた走行可能領域の抽出法と交差点検出法は, 本稿で提案した手法を 組み合わせ用いた。提案手法と比較する手法は, 反射強度の実験值から分離曲線を求め, 材質の区別を図る手法 （伊達他, 2013）と, 本稿で述べた格子進入可否判定法を蓄積しない手法を用いる. 分離曲線は, 図 2 から最小二 乗法より算出する. 本実験において, アスファルトと芝それぞれの反射強度の值の平均值の中間值を線形近似から 得た $f(x)=0.08 x+16.9$ を用いた. $\gamma_{\left(r_{k}, \theta_{k}\right)} / f(x)$ が 1 以上であるときの点群を走行不可点群，そうでなければ走行 可能点群とする. 実験では, 図 5（a）に示した研究学園前公園内の交差点と道より構成されている環境において, 交差点 15 箇所及び交差点（始点と終点を含む）同士を結ぶ道 16 箇所，計 31 箇所に対して交差点検出することで 精度を評価する. 図 5（a）に示している交差点の数字とピークの本数が一致した時を正解とする．また，ピーク の本数が 2 本の時を道と判定する.つまり混合行列は

· True Positive（真陽性）: 交差点に対して，図 5（a）に示している数字とピークの本数が一致

· False Negative（偽陰性）：交差点に対して，図 5（a）に示している数字とピークの本数が不一致

· False Positive (偽陽性) : 道に対して, ピークの本数が 2 本以外

· True Negative（真陰性）: 道に対して, ピークの本数が 2 本

として精度を評価する．道や交差点 1 箇所に対して 1 つの判定を行うため，“False”の判定が出た時点で “False”の 判定とした。また今回の精度評価では，ピークの角度や長さは考慮していない. 


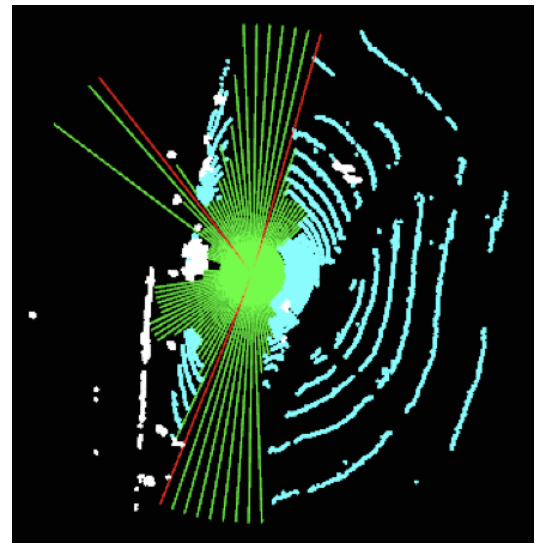

(a)

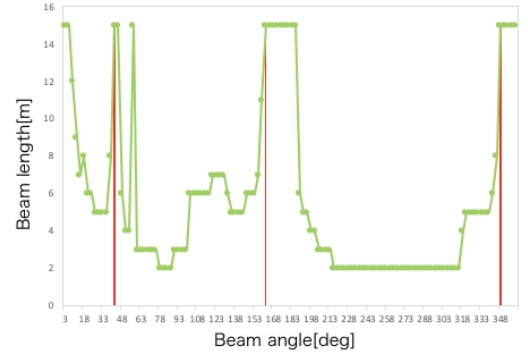

(d)

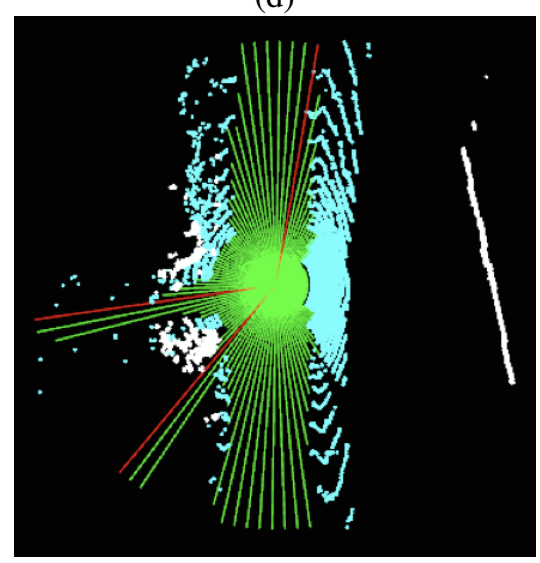

(g)

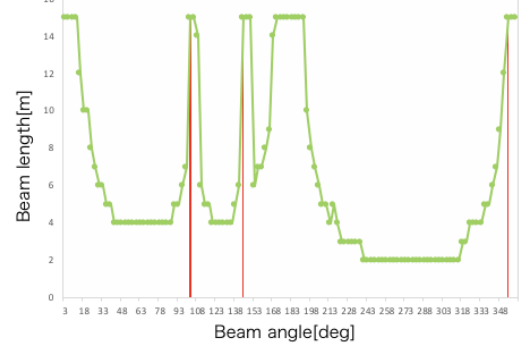

(j)

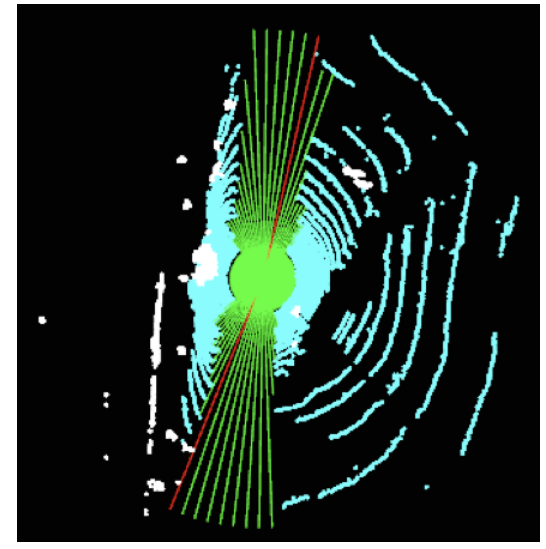

(b)

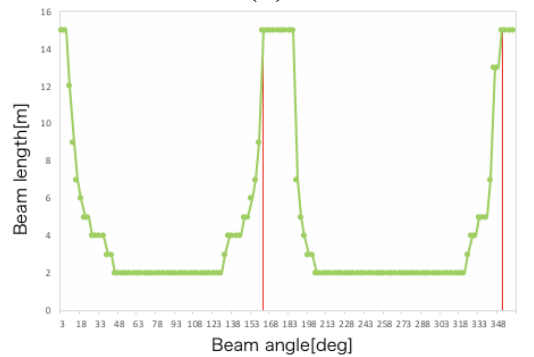

(e)

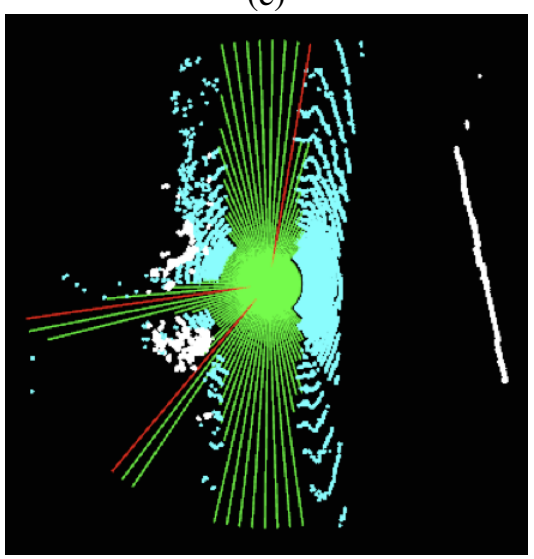

(h)

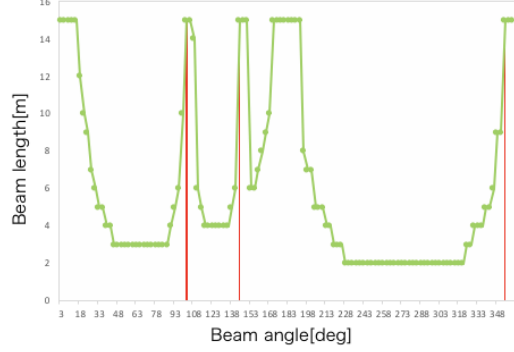

(k)

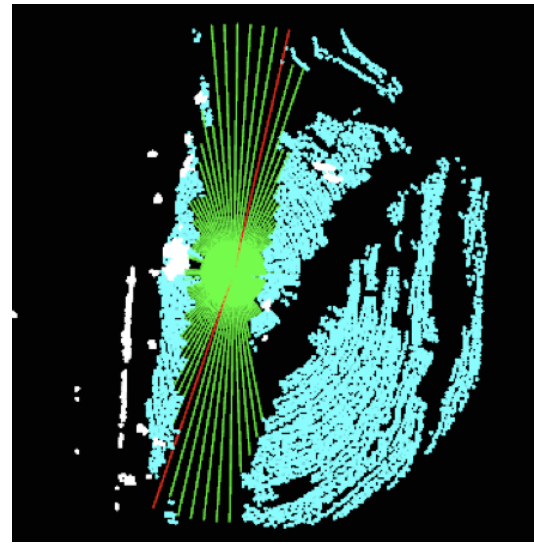

(c)

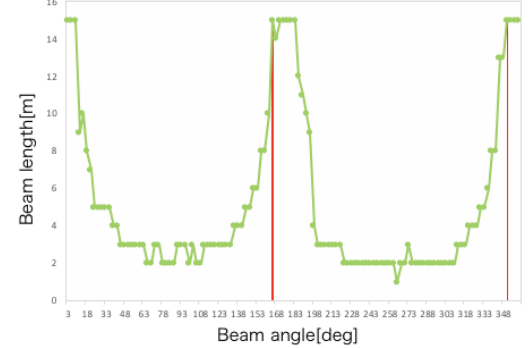

(f)

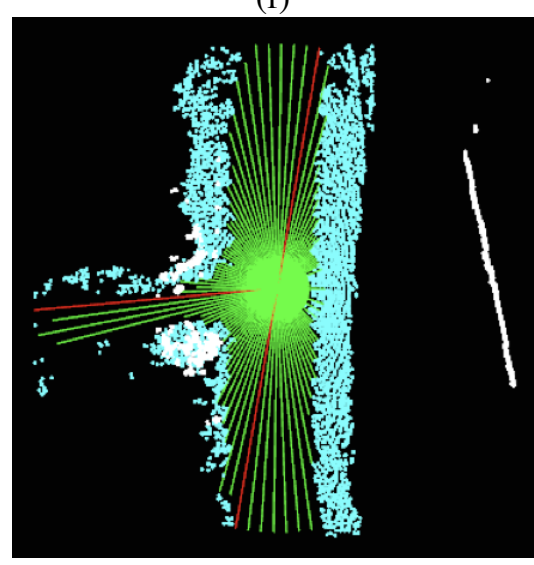

(i)

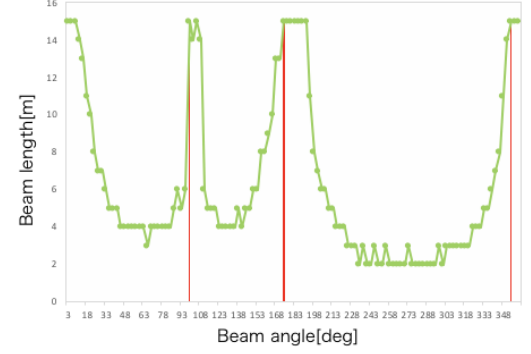

(1)

Fig. 6 Odd rows show intersection extraction by beam model, and even rows show corresponding distance function. The partition line method is used at Image(a) (d) (g) (j). The unaccumulated method is used at Image(b) (e) (h) (k). The proposed method is used at Image(c) (f) (i) (l). Image(a) - (f) shows that each method detects the intersection at spot(a) in image 5(b). Image $(\mathrm{g})$ - (l) show that each method detects the intersection at spot(b) in image 5(b).

\section{$3 \cdot 2$ 結果}

精度評価をする上で，実験環境で，検出された交差点に対して Precision（適合率）, Recall（再現率）及びAccuracy （正解率）という点で評価を行う. 実験結果より得られた Precision, Recall 及び Accuracy を表 1 に示す。表 1 よ 
り Precision, Recall 及び Accuracy 共に提案手法の方が高いことが分かる. Precision が高いことから提案手法は他 の手法と比べ，交差点と判定した場合には交差点である確率が高いことを示している．また，Recall が高いことか ら提案手法は他の手法と比べ，交差点に対して交差点と判定する確率が高いことを示している. 従来手法と，走 行可能領域を蓄積しない手法と，提案手法の比較を図 6 に示す。眓 $6(\mathrm{a}) \sim(\mathrm{c}),(\mathrm{g}) \sim(\mathrm{i})$ にそれぞれの手法 で交差点認識している様子を示している. 図6（a）〜（f）は，図 5（b）のA の場所にいる時の道に対する交差 点検出している図である. 図 6（b）,（c）は道に沿った領域を検出していることに対し，従来手法では走行可能領 域を正確に抽出が出来ていない。そのため, 交差点と誤検出しているのが見受けられる。図 $6(\mathrm{~g}) \sim(1)$ は, 図 5 （b）の B の場所にいる時に, 動的物体によりオクルージョンが生じた中での交差点検出している図である. 図 6 (g)，（h）は，オクルージョンにより点群が正確に得られず，誤った交差点検出を行っている. 対し，図 6（i） は, ${ }^{\text {lidar }} p_{\text {road }}$ を蓄積しているため, 正確に交差点検出していることが読み取れる. また本手法において誤認識し た場所は，広場のような交差点（ $36^{\circ} 08^{\prime} 12.68^{\prime \prime} \mathrm{N}, 140^{\circ} 08^{\prime} 16.11^{\prime \prime} \mathrm{E}$ ）で交差点と認識出来ず， 3 種類の材質 を含んだ道（36 $\left.07^{\prime} 99.20^{\prime \prime} \mathrm{N}, 140^{\circ} 08^{\prime} 04.88^{\prime \prime} \mathrm{E}\right)$ で誤って交差点と誤った判定を行ってしまった。広場のよ うな環境では設定したパラメータでの交差点検出をすることが困難だったこと．また，地面の材質に対して二值 化を行っていることが原因と考える.

\section{4. 結言}

本稿において，離散化した空間上の同距離にある点群同士での反射強度による比較から交差点を検出する手法 を提案した. 幾何学的特徵がそしい環境において, 反射強度を用いることでロボットのための走行可能である領域 を検出することを可能とした。交差点と道を含む環境での実験から，距離補正だけでの反射強度による比較より も本手法は有用であることを示した。しかし現状での研究では，例外的に反射強度が異常な点（ロードマーカや 金属反射など）や多数の材質を含む環境，路面と区別したい材質が路面に近い反射強度の場合，走行可能領域を 適切な判定することは困難である.今後の発展として, 地面の材質を区別する手段に反射強度の 1 軸以外に軸を 増やすことで, さらに精度が向上すると思われる。例として, 波長が異なる複数のレーザーセンサの使用やレー ザーセンサとイメージセンサとの組み合わせることが挙げられる.

謝 辞

本研究の一部は, 国立研究開発法人新エネルギー・産業技術総合開発機構（NEDO）の, 次世代人工知能・ロ ボット中核技術開発事業による支援を受けた.ここに篤く御礼申し上げる.

文献

Armesto, L., Minguez, J. and Montesano, L., A generalization of the metric-based iterative closest point technique for 3D scan matching, Robotics and Automation, Proceedings of IEEE International Conference on Robotics and Automation (ICRA) (2010).

Chen, T., Dai, B., Liu, D. and Liu, Z., Lidar-based long range road intersection detection, Image and Graphics (ICIG) (2011).

伊達央, 大川 真弥, 滝田 好宏, 菊地 惊, 地表面の反射輝度を活用した自律移動ロボットの高精度自己位置推定. 日本 機械学会論文集 C 編, Vol.79, No.806(2013),pp.3389-3398.

Hata, A. Y. and Wolf, D. F., Feature detection for vehicle localization in urban environments using a multilayer LIDAR, IEEE Transactions on Intelligent Transportation Systems, Vol.17, Issue 2 (2016).

Hosoda, Y., Sawahashi, R., Machinaka, N., Yamazaki, R., Sadakuni, Y., Onda, K., Kusakari, R., Kimba, M., Oishi, T. and Kuroda, Y., Robust road-following navigation system with a simple map, Journal of Robotics and Mechatronics, Vol.30, No.4 (2018).

Hu, J., Razdan, A., Femiani, J. C., Cui, M. and Wonka, P., Road network extraction and intersection detection from aerial images by tracking road footprints, IEEE Transactions on Geoscience and Remote Sensing (2007).

Macedo, J., Manduchi, R. and Matthies, R., Ladar-based discrimination of grass from obstacles for autonomous navigation, Experimental Robotics VII. Springer, Berlin, Heidelberg (2001). 
Otsu, N., A threshold selection method from gray-level histograms, IEEE transactions on systems, man, and cybernetics, Vol.9, Issue 1 (1979).

Saarinen, J., Andreasson, H., Stoyanov, T. and Lilienthal, A. J., Normal distributions transform Monte-Carlo localization (NDT-MCL), Preceedings of IEEE/RSJ International Conference on Intelligent Robots and Systems (IROS) (2013).

Thrun, S., Burgard, W. and Fox, D., Probabilistic Robotics, The MIT press (2005).

Thrun, S. et al., Stanley: The robot that won the DARPA Grand Challenge, Journal of field Robotics, Vol.23, Issue 9 (2006).

渡辺敦志, 阪東茂, 品田和洋, 油田信一, 方位検出と交差点認識を用いた道なり走行ベースの屋外自律ナビゲーショ ン, 日本ロボット学会誌, Vol.30, No.3 (2012), pp.271-279.

Zhang, Y., Wang, J., Wang, X., Li, C. and Wang, L., 3D lidar-based intersection recognition and road boundary detection method for unmanned ground vehicle, Intelligent Transportation Systems (ITSC) (2015).

\section{References}

Armesto, L., Minguez, J. and Montesano, L., A generalization of the metric-based iterative closest point technique for 3D scan matching, Robotics and Automation, Proceedings of IEEE International Conference on Robotics and Automation (ICRA) (2010).

Chen, T., Dai, B., Liu, D. and Liu, Z., Lidar-based long range road intersection detection, Image and Graphics (ICIG) (2011).

Date, H., Ohkawa, S., Takita,Y. and Kikuchi, J., High precision localization of mobile robot using LIDAR intensity of surface, Transactions of the Japan Society of Mechanical Engineers, Series C, Vol. 79, No.806 (2013), pp.3389-3398 (in Japanese).

Hata, A. Y. and Wolf, D. F., Feature detection for vehicle localization in urban environments using a multilayer LIDAR, IEEE Transactions on Intelligent Transportation Systems, Vol.17, Issue 2 (2016).

Hosoda, Y., Sawahashi, R., Machinaka, N., Yamazaki, R., Sadakuni, Y., Onda, K., Kusakari, R., Kimba, M., Oishi, T. and Kuroda, Y., Robust road-following navigation system with a simple map, Journal of Robotics and Mechatronics, Vol.30, No.4 (2018).

Hu, J., Razdan, A., Femiani, J. C., Cui, M. and Wonka, P., Road network extraction and intersection detection from aerial images by tracking road footprints, IEEE Transactions on Geoscience and Remote Sensing (2007).

Macedo, J., Manduchi, R. and Matthies, R., Ladar-based discrimination of grass from obstacles for autonomous navigation, Experimental Robotics VII. Springer, Berlin, Heidelberg (2001).

Otsu, N., A threshold selection method from gray-level histograms, IEEE transactions on systems, man, and cybernetics, Vol.9,Issue 1 (1979).

Saarinen, J., Andreasson, H., Stoyanov, T. and Lilienthal, A. J. , Normal distributions transform Monte-Carlo localization (NDT-MCL), Preceedings of IEEE/RSJ International Conference on Intelligent Robots and Systems (IROS) (2013).

Thrun, S., Burgard, W. and Fox, D., Probabilistic Robotics, The MIT press (2005).

Thrun, S. et al., Stanley: The robot that won the DARPA Grand Challenge, Journal of field Robotics, Vol.23, Issue 9 (2006).

Watanabe, A., Bando, S., Shinada, K. and Yuta, S., Road-following-based navigation in park and pedestrian street with finding intersection and orientation detection, Journal of the Robotics Society of Japan, Vol.30, No.3 (2012), pp.271279 (in Japanese).

Zhang, Y., Wang, J., Wang, X., Li, C. and Wang, L., 3D lidar-based intersection recognition and road boundary detection method for unmanned ground vehicle, Intelligent Transportation Systems (ITSC) (2015). 